\title{
Factors influencing the Consumption Pattern of Male Cosmetics in Delhi by an Urban Male
}

\author{
Sangeeta Gupta ${ }^{1}$ Simple Arora ${ }^{2}$ \\ ${ }^{1}$ (Department of Commerce, Delhi College of Arts \& Commerce, University of Delhi) \\ ${ }_{2}^{2}$ (Department of Commerce, Shyam Lal College(M) ,University of Delhi)
}

\begin{abstract}
This study appraise in depth the pursuance of self image, societal expectations and media (celebrity endorsement and advertisements) on the consumption pattern of urban male towards male cosmetics in Delhi. Also, this study endeavours to find out the reasonable impact of perception on the association of various variables and consumption pattern. The primary data was collected through administration of questionnaire which was circulated to the men who fall in the category of age between 15-45 years living in Delhi. The sample consists of 162 respondents. The study reveals the sizeable variables that affect urban male consumption pattern and attitude towards male cosmetics. The result of the study reinforced an existence of the relationship between self image, media (celebrity endorsement and advertisements) and societal expectation and consumption pattern. Apart from this, the study also provides valuable insight towards the understanding on how perception balanced the relationships between the variables studied and its influence on the consumption pattern of urban male toward male cosmetics products.
\end{abstract}

Keywords: Consumption pattern, Male cosmetics, Media self image, Societal expectation Urban male.

\section{Introduction}

With the technological advancement, globalization and increased purchasing power, consumers have become more conscious of hygiene and beauty which leads to rapid growth in male cosmetics industry. The market potential of this era had led the cosmetics and health clubs industries to enter this opportunistic male grooming industry as men become more image -conscious and concerned towards societal expectation on the basis of their increased exposure to the current highly popularized emergence of metro sexual celebrity endorsement as per AMA ${ }^{[1]}$. It is true that the market of grooming products is growing exponentially but the success or failure of a product's brand is dependent on its ability to appeal to the new customers, which are still not in a ready state to enter a zone perceived as women's only zone.

In the released survey by The NPD Group ${ }^{[2]}$, a leading market research company of New York, men is continuously finding new benefits of keeping up appearances. Men's grooming and cosmetic products are among the largest monetary growth drivers in totality of personal care industry and product categories like men's cosmetics specifically face creams steadily growing at a rapid speed." Grooming of men's in India has risen by $22 \%$ in current value terms in 2012 , to reach Rs 37.9 billion. Most of the big players within beauty and personal care launched products specific to males in 2012. The male cosmetics market in India is still not developed and in its infancy stage. The initial stage of Indian market is an opportunity to various cosmetics companies which are designing and planning their strategies to attract and target male consumers in upcoming years. This case will definitely be beneficial to the companies which will enter first in terms of product acceptability among male consumers. The market is forecasted to witness a double digit growth in coming years because of change in lifestyle and increasing spending among male consumers. As we all can see grooming products and male cosmetics can now be found under brands such as Garnier, Nivea, Fiama Di Wills and Olay. Men are increasingly accepting to use products that were earlier considered the domain of women.

According to Mr Sanjay Singal, marketing head, beauty care at Dabur India Ltd, men are increasingly becoming the drivers of growth for the Indian cosmetic market. Also emphasized that the belief of a men that how a person presents himself to the outer world is important for the social acceptance has moved a step forward understanding the importance of presenting nicely will certainly be an advantage to his career.

Even nowadays the other sectors like Fast Moving Consumer Goods (FMCG) ${ }^{[3]}$ are increasingly trying to lure male consumers which was earlier just focussing on traditional products like deodorant etc. The companies have extended their presence to specialized skin creams and bleaches also. The market segment of deodorants - a category that has players such as HUL, Godrej, Nivea among many other smaller brandsclocked a $46 \%$ growth, the fastest as per Euromonitor ${ }^{[4]}$.

\section{Objectives}

1. To establish the impact of self image, societal expectation and media (Celebrity and advertisement) on the urban males and its relationship with the consumption of male cosmetics 
2. To determine the reasonable effects of perception towards the consumption of male cosmetics

\section{Literature Review}

A study conducted by Blanchin, Chareyron and Levert at University of Halmstad School of business and Engineering ${ }^{[5]}$ under the head "The customer behaviour in the men's cosmetics market" examines the impact of theories of self concept on the consumer buying of male cosmetics and concluded that there exist a strong relationship between self concept and purchase pattern. Study shows that most of the time men are using products to improve their self image and for themselves only.

As per studies of Dr.Vinith Kumar Nair and Dr. Prakash Pillai ${ }^{[6]}$,titled ,"A Study on Purchase Pattern of Cosmetics among consumers in Kerala " revealed that usually male consumers tend to buy nad decide their brands on their own.They take purchasing decision independently as per individual requirement. The factor which affect the choice is quality of the product .The other factor found impacting the preference was the purchasing of cosmetics from single shop driven by convenience. The average spending on cosmetics was claimed to be between Rs. 300 and Rs. 500 by male buyers in comparison to female purchasers.

In the studies by Margaret K.H., Alastair \& Kathy ${ }^{[7]}$ titled "Social others" interprets the as important interprets the meaning of consumption choices to consumers. As per Wienke, C. ${ }^{[8]}$, with the use of body movement, decoration, clothing etc men try to improve their choices. In Japan, fashionable is a social norm for men as per Mc Cracken ${ }^{[9]}$. The buying of a product is affected by its social environment in terms of which product to buy according to Nizar \& MAriam ${ }^{[10]}$. As per Cardona ${ }^{[11]}$, the trend of casual dressing on Fridays and attitude change also contributes to the buying of grooming products. Also, Carole ${ }^{[12]}$ found the consumption of male cosmetics related to the acceptance by their social friend circle.

\section{Conceptual Framework}

The use of cosmetics by a male is not for its tangible benefits but the motivation behind is to have a strong identity. The consumption of cosmetics by men helps them to change their self image to suit the different roles in their lives. It is not required to elaborate much as today's trend indicates the pressure of social expectations on urban male to look better and vibrant. It is the societal expectations which motivate them to consume cosmetics. With the increasing exposure of media the men are expected to be updated with the latest trend be it cosmetics or anything else. The choice of cosmetics is influenced by their favourite magazines or sometimes by their favourite celebrity endorsing it.

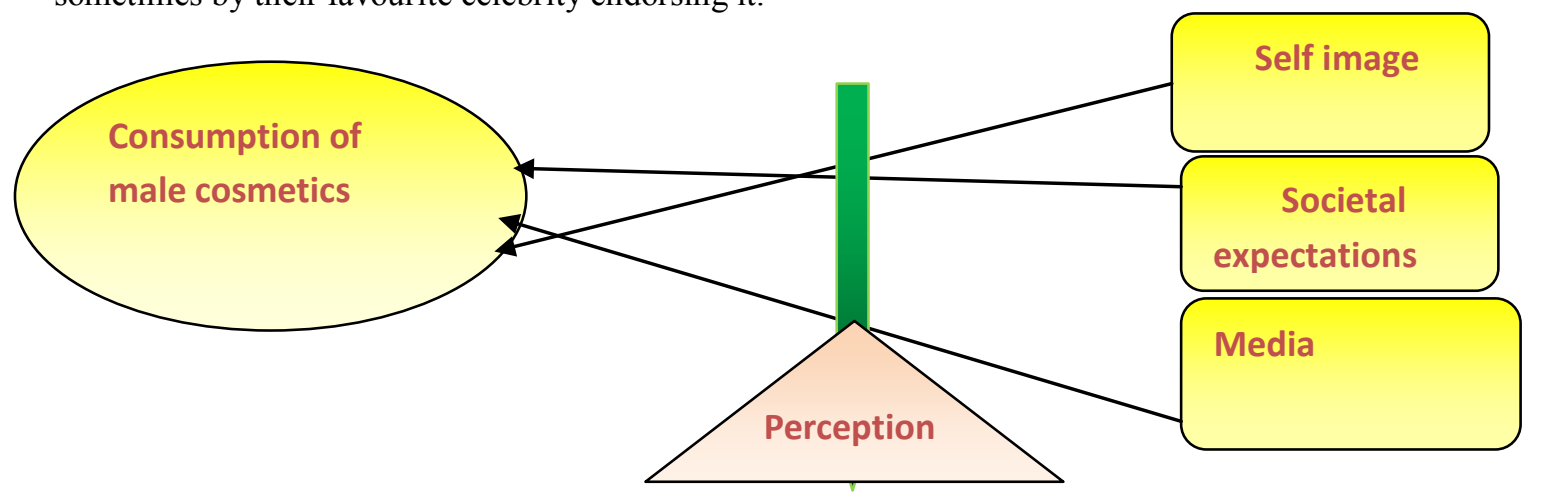

\section{Primary Data Collection}

\section{Research Methodology}

The survey method was used to collect primary data quantitatively. The selection criterion was restricted to men aged 18-45 years belonging to all classes with various demographic profiles in terms of occupation, income of Delhi. The technique employed was non-probability; convenience sampling. It was adopted due to its benefits like convenience, accessibility and fast inputs. The respondents were selected as walk-ins to various malls of different regions of Delhi.

A total of 168 questionnaires were distributed and 162 out of them have completed, implying $96.4 \%$ rate of response. The Questionnaire includes five constructs i.e. self image, media, societal expectations, perception and consumption. Each construct had minimum two questions and maximum eight questions with an itemized - likert ranking scale of 1 to 5 ( 1 =strongly disagree, $2=$ disagree, $3=$ neutral, $4=$ agree, $5=$ strongly agree). The questionnaire consisted of 2 parts; personal data and consumption data. Personal data started from question number 1 to question number 5. All questions in personal data part asked about name, age, marital status, occupation and income. In consumption part, it started from question number 6 to question number 30 . 


\section{Data Analysis And Interpretation}

\subsection{Data}

The demographic profiles of the respondents are shown in Table 1. The majority of respondents are below the age of 40 years (71.6\%). Sixty one percent of respondents are single and more than seventy percent of the respondents are students or of service class. Almost eighty percent of respondents reported Family's Monthly Income of more than Rs. 30,000.

\begin{tabular}{|c|c|c|c|}
\hline \multicolumn{4}{|c|}{ Table 1: Demographic Characteristics of Respondents } \\
\hline S. No. & Characteristics & Category & Total \\
\hline \multirow[t]{3}{*}{1} & \multirow[t]{3}{*}{ Age } & Less than 30 & 49 \\
\hline & & 30 to 40 & 67 \\
\hline & & more than 40 & 46 \\
\hline \multirow[t]{2}{*}{2} & \multirow[t]{2}{*}{ Marital Status } & Single & 99 \\
\hline & & Married & 63 \\
\hline \multirow[t]{3}{*}{3} & \multirow[t]{3}{*}{ Occupation } & Student & 42 \\
\hline & & Service & 73 \\
\hline & & Business/Professional & 47 \\
\hline \multirow[t]{5}{*}{4} & \multirow[t]{5}{*}{$\begin{array}{c}\text { Family's } \\
\text { Monthly Income }\end{array}$} & Less than 20,000 & 13 \\
\hline & & 20,001 to 30,000 & 17 \\
\hline & & 30,001 to 40,000 & 22 \\
\hline & & 40,001 to 50,000 & 63 \\
\hline & & 50,001 and above & 47 \\
\hline
\end{tabular}

\subsection{Statistical Analysis}

The collected data was statistically analysed using SPSS 19.0. Factor analysis was carried out to reduce the number of variables from large to small. KMO (Kaiser-Meyer-Olkin) measure of sampling adequacy results are displayed in Table 2.The value of KMO (0.585) and Bartlett's test (0.000) shows the compatibility of data to use factor analysis.

Table 3 shows the communalities before and after extraction. Initial communalities are, for correlation

\begin{tabular}{|l|l|c|}
\hline \multicolumn{2}{|c|}{ Table 2: KMO and Bartlett's Test } & 0.585 \\
\hline Kaiser-Meyer-Olkin Measure of Sampling Adequacy. & Approx. Chi-Square & 1034 \\
\hline Bartlett's Test of Sphericity & d.f & 276 \\
\cline { 1 - 2 } & sig. & 0.000 \\
\hline
\end{tabular}

analyses, the proportion of variance accounted for in each variable by the rest of the variables. The column Extraction demonstrates the extraction as $61.3 \%$ which is common in the data set. This variance is connected to first question which is common or shared variance.

\begin{tabular}{|l|c|c|}
\hline \multicolumn{2}{|c|}{ Variables } & \multicolumn{1}{|c|}{ Initial } \\
\hline Self Image & 1 & \multirow{2}{*}{ Extraction } \\
\hline Look for ideal hairstyle & 1 & 0.613 \\
\hline $\begin{array}{l}\text { Use grooming product for } \\
\text { presentable image }\end{array}$ & 1 & 0.573 \\
\hline Check appearance Frequently & 1 & 0.515 \\
\hline Buy clothes that suits best & 1 & 0.708 \\
\hline $\begin{array}{l}\text { Use different product to create } \\
\text { intended image }\end{array}$ & 1 & 0.685 \\
\hline Concerned about appearance & 1 & 0.622 \\
\hline
\end{tabular}




\begin{tabular}{|c|c|c|}
\hline Feel embarrassed if not looked best & 1 & 0.563 \\
\hline Make best efforts to look best & 1 & 0.481 \\
\hline \multicolumn{3}{|l|}{ Celebrity } \\
\hline Fan of good looking male celebrities & 1 & 0.701 \\
\hline $\begin{array}{l}\text { Feel look alike as using } \\
\text { endorsed product }\end{array}$ & 1 & 0.746 \\
\hline $\begin{array}{l}\text { Uses bejewelled products } \\
\text { as favourite celebrity }\end{array}$ & 1 & 0.662 \\
\hline Keeping hair as of celebrity & 1 & 0.674 \\
\hline Imitate a celebrity to buy & 1 & 0.743 \\
\hline Like to look younger as my actual age & 1 & 0.720 \\
\hline Comparison with celebrity & 1 & 0.643 \\
\hline \multicolumn{3}{|l|}{ Societal Expectations } \\
\hline $\begin{array}{l}\text { Differentiate professional and } \\
\text { personal fields }\end{array}$ & 1 & 0.803 \\
\hline Look attractive with groomed look & 1 & 0.770 \\
\hline Like to look young in eyes of others & 1 & 0.640 \\
\hline $\begin{array}{l}\text { Buy cosmetics to have flawless } \\
\text { skin as others }\end{array}$ & 1 & 0.634 \\
\hline \multicolumn{3}{|l|}{ Perception } \\
\hline Proud of being labelled urban male & 1 & 0.710 \\
\hline $\begin{array}{l}\text { Confident being perceived as } \\
\text { desirable }\end{array}$ & 1 & 0.696 \\
\hline \multicolumn{3}{|l|}{ Consumption } \\
\hline Gives satisfaction & 1 & 0.657 \\
\hline $\begin{array}{l}\text { Urge to be updated about } \\
\text { latest cosmetics trend }\end{array}$ & 1 & 0.806 \\
\hline Try new products & 1 & 0.791 \\
\hline
\end{tabular}

Table 4 labelled Total Variance Explained lists the Eigen values associated with each factor before extraction and after extraction and after rotation. There were 24 components of linear nature diagnosed before extraction in the data collected. The eigen values of all factor shows the variance explained by the particular linear component and the table also displays eigen value pertaining to the percentage of variance explained (factor 1 explains $14.884 \%$ of total variance). It shows that first few factors explain relatively large amounts of variance (especially factor 1) but the factors subsequent to first shows only small amount of variance.

\begin{tabular}{|c|c|c|c|c|c|c|c|c|c|}
\hline \multirow[t]{2}{*}{ Component } & \multicolumn{3}{|c|}{ Initial Eigenvalues } & \multicolumn{3}{|c|}{$\begin{array}{c}\text { Extraction Sums of Squared } \\
\text { Loadings }\end{array}$} & \multicolumn{3}{|c|}{ Rotation Sums of Squared Loadings } \\
\hline & Total & $\begin{array}{c}\% \text { of } \\
\text { Variance }\end{array}$ & $\begin{array}{c}\text { Cumulative } \\
\%\end{array}$ & Total & $\begin{array}{c}\% \text { of } \\
\text { Variance } \\
\end{array}$ & $\begin{array}{c}\text { Cumulative } \\
\%\end{array}$ & Total & $\begin{array}{c}\% \text { of } \\
\text { Variance } \\
\end{array}$ & $\begin{array}{c}\text { Cumulative } \\
\%\end{array}$ \\
\hline 1 & 3.572 & 14.884 & 14.884 & 3.572 & 14.884 & 14.884 & 3.452 & 14.382 & 14.382 \\
\hline 2 & 2.619 & 10.911 & 25.795 & 2.619 & 10.911 & 25.795 & 2.066 & 8.609 & 22.99 \\
\hline 3 & 1.892 & 7.885 & 33.68 & 1.892 & 7.885 & 33.68 & 1.948 & 8.117 & 31.107 \\
\hline 4 & 1.779 & 7.414 & 41.094 & 1.779 & 7.414 & 41.094 & 1.928 & 8.035 & 39.142 \\
\hline 5 & 1.566 & 6.524 & 47.618 & 1.566 & 6.524 & 47.618 & 1.594 & 6.642 & 45.784 \\
\hline
\end{tabular}


Factors influencing the Consumption Pattern of Male Cosmetics in Delhi by an Urban Male

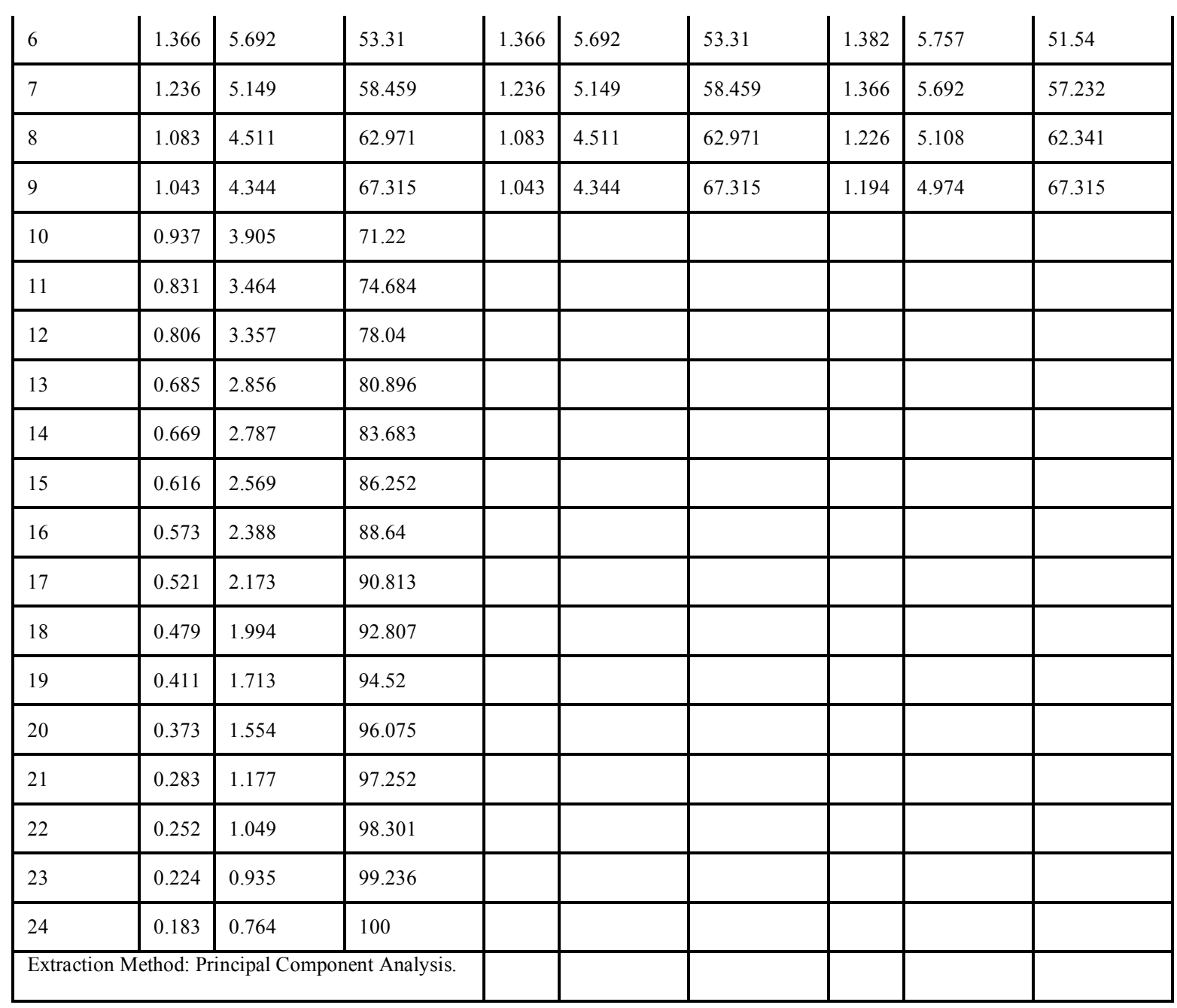

Table 5 labelled explains the Component Matrix before rotation. The Component Matrix includes the loading of each variable onto each factor. As calculated that all loading below 0.3 is dropped in the next table to avoid the blank for many of the loadings.

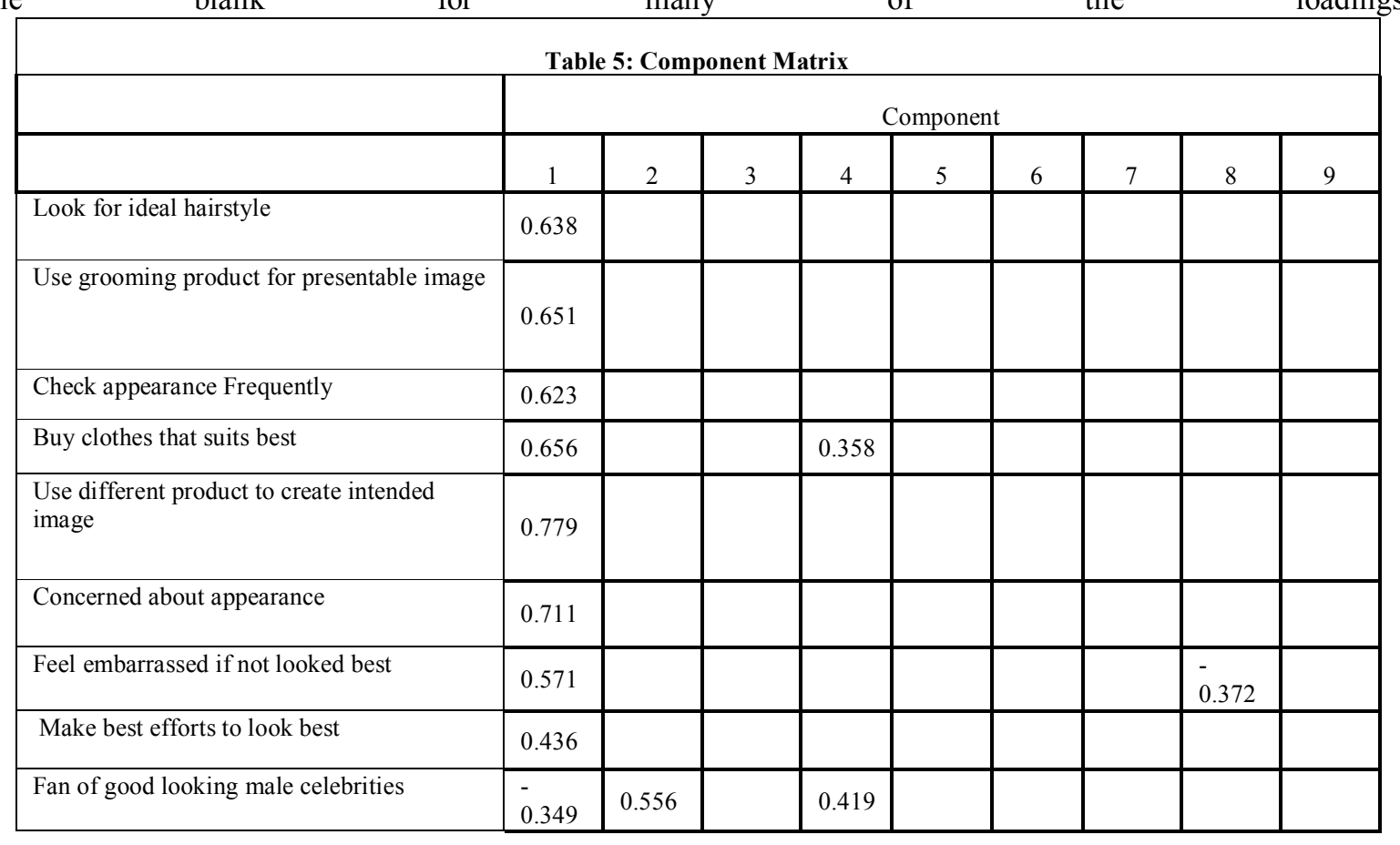




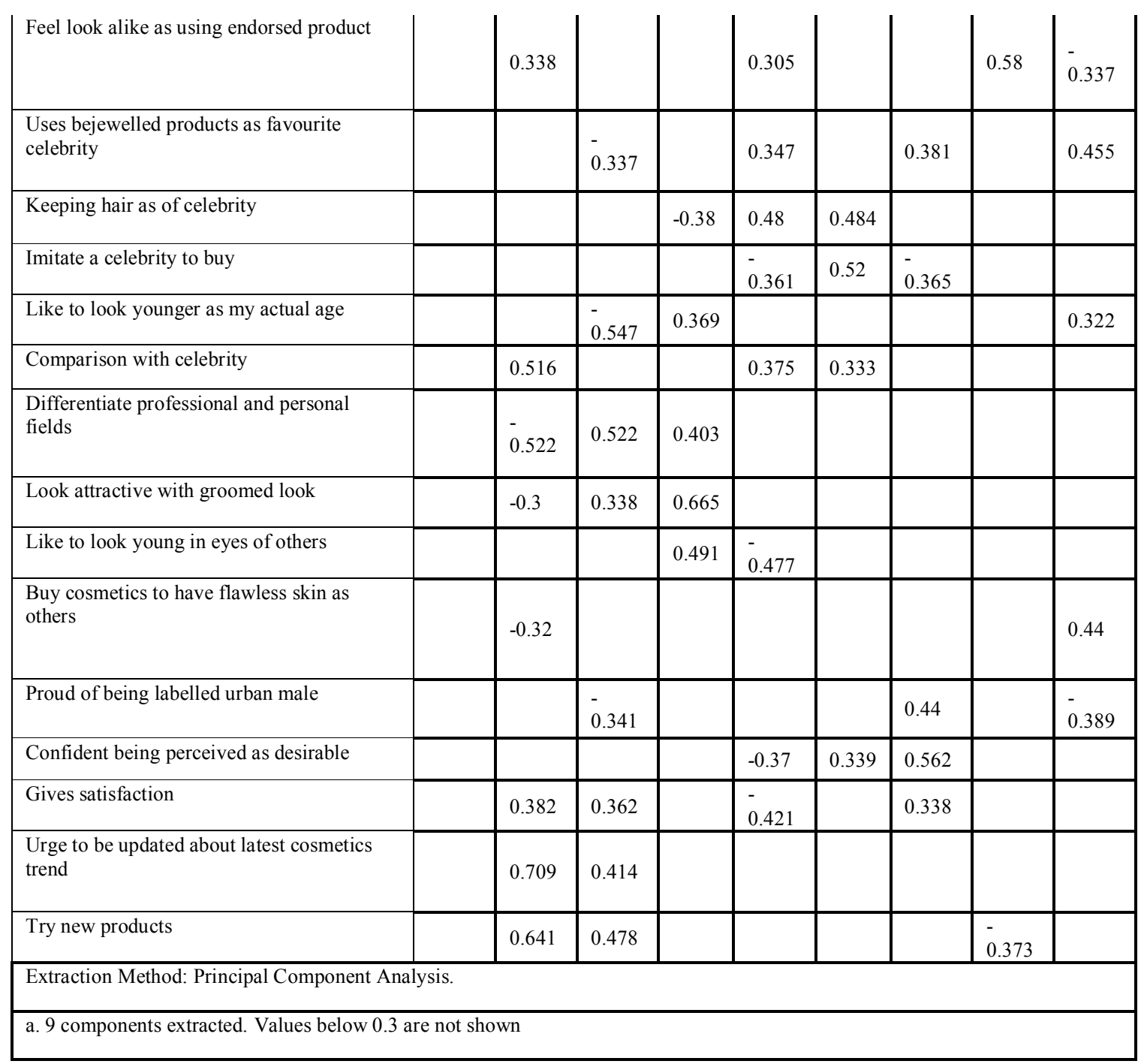

Table 6, labelled Rotated Component Matrix consists of same information as of component matrix which is calculated after rotation.

\begin{tabular}{|c|c|c|c|c|c|c|c|c|c|}
\hline \multicolumn{10}{|c|}{ Table 6:Rotated Component Matrix ${ }^{a}$} \\
\hline & \multicolumn{9}{|c|}{ Component } \\
\hline & 1 & 2 & 3 & 4 & 5 & 6 & 7 & 8 & 9 \\
\hline Look for ideal hairstyle & 0.599 & & & $\overline{-}-301$ & & & 0.319 & & \\
\hline $\begin{array}{l}\text { Use grooming product for presentable } \\
\text { image }\end{array}$ & 0.663 & & & & & & & & \\
\hline Check appearance Frequently & 0.635 & & & & & & & & \\
\hline Buy clothes that suits best & 0.706 & & & & 0.302 & & & & \\
\hline $\begin{array}{l}\text { Use different product to create intended } \\
\text { image }\end{array}$ & 0.74 & & & & & & & & \\
\hline Concerned about appearance & 0.734 & & & & & & & & \\
\hline Feel embarrassed if not looked best & 0.562 & & & & & & & & -0.39 \\
\hline Make best efforts to look best & 0.488 & & & & & & & & \\
\hline
\end{tabular}




\begin{tabular}{|c|c|c|c|c|c|c|c|c|}
\hline Fan of good looking male celebrities & & & 0.711 & & & & & \\
\hline Feel look alike as using endorsed product & & & & & & & & \\
\hline & & & & & & & & 0.83 \\
\hline $\begin{array}{l}\text { Uses bejewelled products as favourite } \\
\text { celebrity }\end{array}$ & & & & & & & 0.755 & \\
\hline Keeping hair as of celebrity & & & & 0.809 & & & & \\
\hline Imitate a celebrity to buy & & & & & & 0.819 & & \\
\hline Like to look younger as my actual age & & & 0.368 & 0.454 & & 0.41 & & \\
\hline Comparison with celebrity & & & 0.728 & & & & & \\
\hline $\begin{array}{l}\text { Differentiate professional and personal } \\
\text { fields }\end{array}$ & & 0.848 & & & & & & \\
\hline Look attractive with groomed look & & 0.858 & & & & & & \\
\hline Like to look young in eyes of others & & 0.474 & & 0.496 & & & $\overline{-}-331$ & \\
\hline $\begin{array}{l}\text { Buy cosmetics to have flawless skin as } \\
\text { others }\end{array}$ & & 0.415 & $\overline{-}-342$ & & & & 0.429 & \\
\hline Proud of being labelled urban male & & & & & 0.755 & & & \\
\hline Confident being perceived as desirable & & & -0.34 & & 0.669 & & & \\
\hline Gives satisfaction & 0.634 & & & & & & & 0.307 \\
\hline $\begin{array}{l}\text { Urge to be updated about latest cosmetics } \\
\text { trend }\end{array}$ & 0.86 & & & & & & & \\
\hline Try new products & 0.774 & & & & & & & \\
\hline \multicolumn{9}{|c|}{$\begin{array}{l}\text { Extraction Method: Principal Component Analysis. } \\
\text { Rotation Method: Varimax with Kaiser Normalization. }\end{array}$} \\
\hline
\end{tabular}

\subsection{Interpretation of Statistical Analysis}

On the basis of factor analysis, following components came out as the most important factors:

Component 1: From the rotated matrix the respondent have recognized these factors to be most important factors with the highest explained variance of $14.38 \%$. Eight out of twenty four variables load on significantly to this component, which includes look for ideal hairstyle, Use grooming product for presentable image, Check appearance Frequently, Buy clothes that suits best, Use different product to create intended image, Concerned about appearance, Feel embarrassed if not looked best, Make best efforts to look best.

Component 2: From the rotated matrix the respondent have recognized these factors to be most important factors with the highest explained variance of $8.60 \%$. Three out of twenty four variables load on significantly to this component, which includes consumption gives satisfaction, consume to be updated about latest trends and consume new products.

Component 3: From the rotated matrix the respondent have recognized these factors to be most important factors with the highest explained variance of $8.11 \%$. Four out of twenty four variables load on significantly to this component, which includes societal expectations- Differentiate professional and personal fields, Look attractive with groomed look, like to look young in front of others and Buy cosmetics to have flawless skin as others.

Component 4: From the rotated matrix the respondent have recognized these factors to be most important factors with the highest explained variance of $8.03 \%$. Five out of twenty four variables loads on significantly to this component, which includes Fan of good looking male celebrities, Like to look younger as my actual age, Comparison with celebrity, Buy cosmetics to have flawless skin as others and Confident being perceived as desirable. 
Component 5: From the rotated matrix the respondent have recognized these factors to be most important factors with the highest explained variance of $6.64 \%$. Four out of twenty four variables load on significantly to this component, which includes Buy clothes that suits best, keeping hair as of celebrity, like to look younger as my actual age and like to look young in eyes of others.

Component 6: From the rotated matrix the respondent have recognized these factors to be most important factors with the highest explained variance of 5.75\%. Two out of twenty four variables loads on significantly to this component, which includes Proud of being labelled urban male and Confident being perceived as desirable(Perception).

Component 7: From the rotated matrix the respondent have recognized these factors to be most important factors with the highest explained variance of 5.69\%. Three out of twenty four variables load on significantly to this component, which includes Look for ideal hairstyle, Imitate a celebrity to buy and Like to look younger as my actual age.

Component 8: From the rotated matrix the respondent have recognized these factors to be most important factors with the highest explained variance of $5.10 \%$. Three out of twenty four variables load on significantly to this component, which includes Uses bejewelled products as favourite celebrity, like to look young in eyes of others and buy cosmetics to have flawless skin as others.

Component 9: From the rotated matrix the respondent have recognized these factors to be most important factors with the highest explained variance of $4.97 \%$. Three out of twenty four variables load on significantly to this component, which includes Feel embarrassed if not looked best, Feel look alike as using endorsed product and Confident being perceived as desirable.

\section{Conclusion}

The evidence of growing number of males in traditional female market is evident from the analysis. This study investigated the factors affecting blurring gender role in society. The media is playing vital role in attitude change in the societal context. Hence, the analysis it can be clearly stated that there is certainly a strong bond between self image, media, and societal expectations with respect to consumption of cosmetics by an urban male in Delhi. This study will help marketers to tap the upcoming trend of cosmetic consumption by the urban male and design strategies accordingly.

Acceptance of usage of male cosmetics has been on rise among urban Delhi male consumers. The rise in usage is due to enhancing social values pertaining to outwardly appearance of the male individuals. Also, this study gives an insight that perception is an important element that will influence the consumption behaviours of the urban males.

\section{References}

[1]. AMA, Evolution of man ... again, Marketing Management, vol. 16, no. 4, 2007,pp. 6 .

[2]. The NPD Group, Inc., / Consumer Tracking Service, 12 months ending June 2012, https://www.npd.com/wps/portal/npd/us/news/press-releases/pr 120807

[3]. http://timesofindia.indiatimes.com/topic/fmcg

[4]. http://www.euromonitor.com/mens-grooming-in-india/report

[5]. Blanchin, Chareyron and Levert at University of Halmstad School of business and Engineering, the customer behaviour in the men's cosmetics market, (http://hh.diva-portal.org/smash/get/diva2:238020/FULLTEXT01.pdf

[6]. Dr. Vinith Kumar Nair and Dr. Prakash Pillai R, A study on purchase pattern of cosmetics among consumers in Kerala,International Marketing Conference on Marketing \& Society, 8-10 April, 2007, IIMK

[7]. Margaret, K.H., Alastair, J. C. \& Kathy, K., the impact of self-monitoring on image congruence and product/brand evaluation, European Journal of Marketing, vol. 34, no.5/6, 1998, pp. 641-666.

[8]. Wienke, C., Negotiating the male body: men, masculinity, and cultural ideals, The Journal of Men's Studies, vol. 6, no. 2, 1998, pp. 255-282.

[9]. McCracken, M. "Young Japanese men pay big bucks for vanity', JavaScript, no.47, 2003,pp. 6-6.

[10]. Nizar, S., \& Mariam, D. "Canadian and French men's consumption of cosmetics: a comparison of their attitude and motivation" Journal of Consumer Marketing, vol. 26, no. 2, 2009,pp. 97-109.

[11]. Cardona. M.M. “Vanity, thy name is .... Man?’ Advertising Age, vol. 71, no. 17, 2000,pp. 24-24.

[12]. Caroline, P. "Reaching to feminine side of men", Marketing week, vol. 28, no. 4, 2005,pp. 38-39. 